Review Article

\section{MAKYUNG AS AN OLDEST FORM OF MALAY TRADITIONAL DANCE DRAMA IN SOUTHEAST ASIA}

\author{
Rosdeen Suboh \\ University of Malaya
}

Corresponding Author

kudin@um.edu.my
Almost all previous studies on the Makyung dance theater concurred that the aforementioned performance was the oldest form of traditional theater amongst the Malays in Southeast Asia. It arrived or started before the arrival of Islam to the Malay Peninsula. Unfortunately, the written record on Makyung only existed at the end of the 18th century. Hence, the exact date on the origin of Makyung is difficult to determine. This means that the main sources of research on Makyung are from oral traditions, including myths, as well as the evidence contained in the self-titled performances, and not only depending the sources of writing, material evident or archaeological materials. Consequently, this article offers that Makyung is the oldest dance theatre in Southeast Asia through the analysis of previous historical records, studies and opinions about stories and elements in the performance structure.

Keywords: Chronological, Three siblings, Dualistic, First daughter, Mak hiang 


\section{INTRODUCTION}

The history and background of Makyung written by renowned academic scholars, such as Ghulam-Sarwar Yousof and Mohamed Ghouse Nasuruddin, generally state that it is still a stage of discussion as there are many assumptions of the local community and still can't be matched by historical facts. Hence, this article is to get deeper understanding based on the data obtained from various sources. The result of this analysis offers to explain and suggest that Makyung is one of the oldest traditional dance dramas in Southeast Asia. Below is a chronology outlined by scholars regarding Makyung's history, and presumptions about the year of Makyung's origins - 1181 AD.

\section{Chronology of Makyung Origin in Southeast Asia}

\begin{tabular}{|c|c|}
\hline Year & Quotation from the sources \\
\hline 1181 & $\begin{array}{l}\text { The Mon Khmer Tribe from the Kingdom of Pattani performed the arts of dancing } \\
\text { based on the faith of King Jayavarman VIII, The King of Angkor who is a Buddhist. }\end{array}$ \\
\hline 1300 & $\begin{array}{l}\text { Makyung was performed in the form of healing ritual 'Main Puteri" during the } \\
\text { ruling of Che Siti Wan Kembang (Kuala Kerai Bukit Kelantan). }\end{array}$ \\
\hline 1304 & $\begin{array}{l}\text { It is said that Sultan Muhammad has forbid and banned the Makyung performance } \\
\text { because it is against the teaching of Islam. }\end{array}$ \\
\hline 1320 & $\begin{array}{l}\text { Makyung dance was presented by the goddess of Durga to Che Siti Wan Kembang } \\
\text { in Kota Kuala Kerai when she ruled Hulu Kelantan }\end{array}$ \\
\hline 1500 & $\begin{array}{l}\text { A dance (believed to be Makyung) was performed by a groups in the palace of } \\
\text { Pattani similar to the one in Java }\end{array}$ \\
\hline 1600 & $\begin{array}{l}\text { A group of women dancers performed in similar manners of the Javanese } \\
\text { (believed to be Makyung) in tanah melayu (Malaya) }\end{array}$ \\
\hline 1700 & $\begin{array}{l}\text { The was a dance performance (believed to be Makyung) accompanied by nobat } \\
\text { in the palaces in tanah melayu }\end{array}$ \\
\hline 1762 & $\begin{array}{l}\text { Mo yong, Manura theaters, joget asyik and gambling arena were performed } \\
\text { during the circumcision ceremony of the son of Long Junos }\end{array}$ \\
\hline 1860 & $\begin{array}{l}\text { Makyung (dancing, singing, and music) was performed during the wedding } \\
\text { ceremony of the Chinese Chieftain and Princess Raja Hamidah in Pulau } \\
\text { Penyengat Riau. }\end{array}$ \\
\hline 1878 & $\begin{array}{l}\text { A performance from the King to celebrate Frank Swettenham di Istana Pahang in } \\
\text { the palace of Pahang consists of dancing, singing, and humor acting (believe to } \\
\text { Makyung). The dance troops moved from one region to another. }\end{array}$ \\
\hline 1896 & $\begin{array}{l}\text { Tengku Mahmod from the Kingdom of Kedah bestowed Tengku Sulaiman a gift } \\
\text { of Makyung performers at the palace of Serdang. The group led by perimadonna } \\
\text { Cik Leha, moved from Kedah to Serdang via Penang where they were then } \\
\text { wedded by the locals. }\end{array}$ \\
\hline 1900 & $\begin{array}{l}\text { The Siamese Makyung used masks worn by the comedians and ghosts. There } \\
\text { were various stories performed using musical instruments such as Cerek, Anak } \\
\text { ayam dan Mong-mong. }\end{array}$ \\
\hline
\end{tabular}




\begin{tabular}{|l|l|}
\hline 1910 & $\begin{array}{l}\text { The locals said that Makyung originated from a comedian called Jemakam and } \\
\text { Syeikh who studied various stories from the Semang tribe (aborigin couple) in the } \\
\text { forest. The move form village to village and spread stories by preaching }\end{array}$ \\
\hline 1920 & Makyung was performed in Siak and Malacca. \\
\hline 1926 & $\begin{array}{l}\text { The establishment of the Temenggung Art Academy by Tengku Abdul Ghaffar. } \\
\text { He gathered Makyung performers from all over the regions and regcognised } \\
\text { their skills. Makyung was widely taught to publics. Makyung form the palace was } \\
\text { altered according to the dictates of the king and the states }\end{array}$ \\
\hline
\end{tabular}

\section{CHRONOLOGICAL ANALYSIS: THE FIRST STAGE $\left(12^{\text {TH }}\right.$ TO $14^{\text {TH }}$ CENTURY)}

From the aforementioned chronology, the history can be divided into three stages. The first stage clearly shows that between $12^{\text {th }}$ to $14^{\text {th }}$ century, Makyung emerged form an ancient dance some 800 years ago. There are many elements that relate the old form of the dance to the current Makyung dance performance. First, Makyung originated form the dance of the Aslian language tribes, who were among the earliest native tribes to reside in the Malay Archipelago; they were from the Mon Khmer ethnic. An example of the Aslian is the Jakun tribe (it is believed that the Jakun who married to the Indians were the ancestors of the Malays in the coastal areas), Semang dan Che Wong (both Semang and Che Wong are the characters in Makyung performance in Riau). A comedian was the first individual to learn the dance ritual from the native tribes and later presented to the public. This depiction is related to the spirit of Jemakam, which is evoked during the ritual of summoning the ancestral spirit in some of previous Makyung performances in Kelantan. At this stage, the structure of the Makyung performance is based on rituals of worshipping spirits. It is related to Ibu Durga (the Goddess) in Hinduism, Lotus Sutra in Mahayana Budhism (a symbol of feminine - grace and love) and ancestral spirits in Thevarada Budhism. These elements can be seen in the performance of Main Puteri Makyung, which is a ritual or a healing process of spiritual and mental illness. There is a ritual of evoking and calling for the spirit of the ancestors during the Makyung ritual performance as dictated by the ancestors in order to express gratitude to the ancestors. In some cases, the spirits of the ancestors were transformed into several characters throughout the ceremony. It is also clearly noticeable through the character of a King, which is played by a woman in every Makyung performance. In this case, Makyung portrays the concept of mother from the word 'Mak' as an individual who is caring, loving, and graceful. 'Mother' also possesses abundant magical power just like Ibu Durga. On the other hand, Makyung as a dance was performed during the ruling of King Angkor, Raja Jayavarman VII (1181-1215) from the Kingdom Patani; alas, no clear evidence to substantiate this claim. Two assumptions can be made: this dance was only performed in the palace and belongs exclusively to the royalty, or it belongs to the commoners - the Aslian of the Mon Khmer tribe in southeast Asia. Later, Makyung was widely performed to other parts of what is now known as Thailand: Pattani, Yala and Naratiwat, and finally reached Kelantan. Due to the absence of the evidence, it can only be presumed that there is the elements of status and ranks (royalty versus commoners) in the Makyung performance. 


\section{CHRONOLOGICAL ANALYSIS: THE SECOND STAGE $\left(16^{\text {TH }}\right.$ TO $18^{\text {TH }}$ CENTURY)}

The second stage of Makyung was between $16^{\text {th }}$ to $18^{\text {th }}$ century. This version of Makyung served as a dance was patron by the royalty of the ancient kingdom of Malay Pattani Langkasuka during the era of the female sibling rulers: Raja Hijau, Raja Ungu and Raja Biru (1584-1635). The Kingdom was widely renowned in the whole Asia for its successful maritime trade. The Royal Pattani Dramatic Company performed a dance called Ala Java in several regions, including Pahang. It uses musical instruments consist of flutes and drums, like the instruments used in a Nobat performance, while the steps are of the Javanese dance from the Java Island. The group members consist of 4 men and 12 young women singers and children. This category of performance was developed and later performed in various courts around the Malay Archipelago, such as Kelantan, Malacca and Pahang. In Kelantan, the dance is called Mo Yong and it was performed by the royalty and the noble members in the palace during circumcision ceremony at the time of Long Yunos as the ruler (1760). Based on Tome Pires' record, at this stage the ala Javanese dance probably thrived in palaces in Java.

\section{CHRONOLOGICAL ANALYSIS: THE THIRD STAGE $\left(19^{\mathrm{TH}}\right.$ TO $20^{\mathrm{TH}}$ CENTURY)}

The third stage of Makyung evolved during the $19^{\text {th }}$ to $20^{\text {th }}$ century (before World War II). This is the most trivial and rapid growth of the Makyung development in Southeast Asia, for there were evidences recorded of the history, elements and the word Makyung itself. At this stage, Makyung is the traditional Malay performance in the Southeast Asia, performed by both the royalty and aristocracy in the palaces and the commoners in villagers in southern Siam, Kelantan, Terengganu, Pahang, Perlis, Malacca, Johor and Kedah; this time, the Makyung performance were led by women. Awang Keladi, a sailor form Riau, traveled to Pattani in 1860 via sea and learned Makyung. He performed and spread the knowledge of Makyung around the isles of Riau, Kalimantan and Batam, and also in Tanjung Kurau, Singapore. In 1860, Makyung was performed in the isles of Riau during the wedding ceremony of the Chinese Chieftain and Princess Hamidah in Pulau Penyengat. Later in 1896, Tengku Mahmod from Kedah had gifted Tengku Sulaiman a group of Makyung performers, led by primadonna Cik Leha, in Serdang, North Sumatera. The troupe had moved from Kedah to Serdang via Penang. They were paid and later married to the locals from nearby regions, such as Perbaungan and Langkat (also known as Pulau Perlis and Pulau Kampai). Until 1900, the structure of Makyung in Pattani, Kedah, Perlis and Kelantan were similar, which consists the elements of ritual performing, healing, singing, dancing, Malay acting, mask wearing, and the characters using the name of Che Wang and Mak Senik as the hero and the heroine respectively. Nevertheless, the development of Makyung in Kelantan between 1879 until 1920 became quite critical due to natural disasters and the influence of the Islamic religious scholars in the governance and royal education. It became more crucial after the death of Sultan Mohamed IV. In 1926, Long Mohamad Jaafar probably changed the structure of Makyung by establishing Temenggung Art Academy, in order to patronage and to recognize the Makyung performers in Kelantan. The elements of ritual, acting, music, dialogue, and dancing were altered to become more compliant of the Islamic teaching. 


\section{THE THEORY OF THREE SIBLINGS}

Moving from the chronological analysis, the historical facts of Makyung can also be presumed as the Makyung origin. In this case, there are four theories of the origin of Makyung. The first one is the three members of a family theory taken from the concept of three siblings: Yong (child), Sa (father) and De (mother). This theory believes that Makyung started from a dance troupe of a family that travels from one place to another. They mastered certain rituals from the ancestors, which were later applied in various forms of creativity, with addition of various beliefs and cultures of the local society. Furthermore, according to the aforementioned theory, Makyung is the product of the local society developed according to their respected heritage. This theory has similarity and related to the meaning of word Makyung as a mother to a daughter Yong or Ayong (Yung), which carries two different meanings: the eldest or first daughter in the Malay family or a chase away. Yong is the eldest daughter of a family of three from Java migrated to Setiu (Terengganu) hundred years ago. When her father died, Yong and her mother were accused of committing adultery, thus they were ostracized by the villagers. They travelled from one place to another until Yong's mother died. As a grieving child, she invented a violin-like instrument from her mother's bones, later known as rebab. She also invented a dance performance with musical characters, in order to ease her grief. In addition, she imitated natures in her dancing. It is said that the performance had caught the interest of the King. In the beginning, the performance was called Yong as she was the pioneer, but later on the word 'mak' was added as a remembrance of Yong's mother during the performance.

\section{THE DUALISTIC THEORY}

The second theory is the dualistic theory, based on the concept of compliment and the balanced of cosmology. It is related to the balanced of two main characters in a Makyung performance such as Pakyung and Makyung, father and mother, Peran muda and Peran tua, and Tok Minduk and Tok Puteri. Both characters are the symbols of the balance in a performance, as well as a balance towards universe and human. This theory is believed by the people in Kelantan, Terengganu, Thailand, Riau and Sumatera. For example, Makyung in both Sumatera and Riau, the characters Awang dan Raja complete the elements of balance in the regional Makyung performance. The character Awang, who is also regarded as 'uri' (placenta), compliments the king as a companion or when they are caught in troubles. In Kelantan, the symbols are believed to be in the characters of Awang Sejambul Lebat and Dewa Muda in the story of Dewa Muda.

\section{THE FIRST DAUGHTER}

The third theory is the concept of the first daughter in the Malay family system (also a symbol of mother, some called Che). This theory supports that Makyung is a play for the women. For example, in Riau, Sumatera and Siam, a male performer playing a male character such as Awang, genie, animal and so on is required to wear a mask to distinguish him from a female performer. The Makyung in Kelantan applies some of the Islamic teaching whereby 
the women are regarded as medium in appraisal of the beauty of God's creation. The theory is also applicable to other traditional performances in Malaysia such as Menora, Nora Chatri, Mek Mulong, and for Makyung in Kedah and Perlis.

\section{THE MAK HIANG THEORY}

Last but not least, the theory of Mak Hiang, which is the concept of fertility. It is also the most popular concept used by scholars who associate the faith of Hinduism, Islam dan Java with women. Makyung is said to be originated from the spirit of the grain (paddy) based on the characters of Dewi Sri and Sedana in the myth of the origin of Paddy spirit. The old word for Makyung is Mak Hiang that derived from the word Mae Yang or Mo Yang. The word Mae is from the Siamese language which means mother or woman or Eva. The word Yang is from the Balinese language that carries meaning of fertility related not only to the micro world that is human, but also to the macro mac world that include crops, soils, trees, etc. While Hiang, Hyang or Huang which means holy, pure, sacred, ancestral, elders, the one, and only, oneness or the beginning in Hinduism. In Java hyang means the decesdants of Adam, and in Bali the word Yang means human anatomy starting from the stomach to the lower back. Therefore, the combination of the words mak and yung become the symbol of fertility whether it's a soil or human being.

\section{CONCLUSION}

Looking at the Makyung development in southeast Asia now, almost all of the performances are still practicing the stated theory. For the conclusion, generally this shows that the elements in the structure that exist today can be used as an element that proves it pertains to the early history of makyung origin. Firstly Makyung is often performed in ceremony during the hervest season of paddy. Malaysia (Kelantan and Kedah), Thailand, Bali and Java are amongst the prosperous regions of Paddy planting and many Makyung performances are used to ask for the prosperity of the harvest. Secondly the lyrics of the song in the segment mengadap rebab in Kelantan consist of the phrases of 'snakes coiled like the incarnate of Dewi Sri in the myth of the paddy spirit. Next, the performance of main puteri uses the story of Dewa Muda and Dewa Penchil as a healing process of certain illness. Also in the mantra during the stage opening of Makyung performance in Kelantan and the isles of Riau there is a mentioned about the fertility of the soil of the village not to be disrupted. The mantra is to evoke the spirits of the elements of the universe such as the soil, wind, fire and water to rise to perfection. The stability of the universe will bring good harvest of the crops. Furthermore, the actions play between Raja and Peran, Awang and Che Wang, Awang Sejambul Lebat and Dewa Muda are the symbols of the born of a new baby together with the placenta. For example in Kelantan, Peran who is also known as the king's attendance acts as a companion, guard, and the cause for human behaviors. Moving right along, stage closing ceremony is meant to wake the audience from the stupor caused by spirit of the ancestors. For example, the acts of brushing the body parts, light exercise, blowing the ears, and tapping the back of the players. 
In addition, the ground opening and closing ceremony in Makyung performance in Riau are also held during the opening of a new land, moving to a new place, or building a new house. The ceremony takes a form of communication between the shaman and the mystical creatures as to get them to agree not to disrupt the balance of the universe. In Riau Makyung is also performed after the ceremony. Finally, in several Makyung stories, there is a symbol of nature such as the Peran of the forest, jungle, swam, mountain and the supreme being. The character of a king must meet this character in the play to solve his problems. As in the story of Makyung Nenek or Gajah Dang Daru in Siam and Riau, this is a symbol of the balance of the sea, water, and land. Dang Daru is the animal symbolizes the sea water that fly to paradise in order to water the land by making the rain fall.

\section{BIBLIOGRAPHY}

A. Kasim Achmad. (2006). Mengenal Teater Tradisional Di Indonesia. Jakarta: Cipta.

Al-Mahadi, A.R (2003). Tamadun Rumpun Budaya Melayu. Kuala Lumpur, Malaysia: Kementerian Kebudayaan Kesenian dan Pelancongan.

Mohamed, A. (1980). Falsafah dan Pemikiran Orang-Orang Melayu: Hubungkaitnya Dengan Islam dan Kesenian. Kuala Lumpur, Malaysia: Kementerian Kebudayaan Belia Dan Sukan Malaysia.

Anatasia Wiwik Swastiwi. (2009). Kesenian Melayu Kepulauan Riau Abad ke 19: Kajian Sejarah Tuhfat al-Nafis, Syair Perkahwinan Anak Kapitan Cina, Syair Perkahwinan Si Komeng dan Syair Perkahwinan Raja Muhammad Yusof dengan Raja Zaleha. Riau: Balai Pelestarian Sejarah dan Nilai Tradisional Tanjung Pinang.

Abdullah, B. (1965) Asal Usul Mak Yong. Kuala Lumpur, Malaysia: Saudara Sinaran.

Banks, D.J. (1976). Trance and Dance in Malaya: The Hindu-Buddhist Complex in Northwest Malay Folk Religion. Council on International Studies. SUNY at Buffalo: Special Studies No. 74, Buffalo: NY.

Noor Din, C.N. (1990) Mak Yong: Satu Analisis Pemain dan Falsafahnya (Latihan Ilmiah). Kuala Lumpur, Malaysia: Jabatan Penulisan Universiti Malaya.

Cuisinier, J.(1936). Danses Magiques de Kelantan. Paris: Travaux et Memoires de l'Institut de'Ethnologie de l'Universite de Paris.

De Danaan, L., \& Arbor, A. (1984). Performance and Transformation: Mystery and Myth in Malay Healing Arts. Michigan: University Microfilms International. 
Yousof, GS. (2004). Panggung Ini: Essays on Traditional Malay Theatre. Kuala Lumpur, Malaysia: Unipress The Centre for The Arts National University of Malaysia.

Mohd Nordin, H. (1999) Mak Yong Kelantan: Satu Kajian Estetika Seni. Kuala Lumpur, Malaysia: Universiti Malaya.

Hasyim Awang, A. R. (1985). Main Peteri: Satu teknik Etnopsikoterapi Masyarakat Melayu Kelantan. Kuala Lumpur: Jabatan Pengajian Melayu Universiti Malaya.

Laderman, C. (1990). Taming The Wind of Desire: Psychology, Medicine, and Aesthetics in Malay Shamanistic Performance. Berkeley: University of California Press.

Nasaruddin, M.G. (2003). Teater Tradisional Melayu. Kuala Lumpur, Malaysia: Dewan Bahasa dan Pustaka.

Ismail, M.A. (1973) .Mak Yong: Sebuah tinjauan dari sudut persembahan (Latihan IImiah). Kuala Lumpur, Malaysia: Jabatan Pengajian Melayu Universiti Malaya.

Yaacob, M.F. (1993). Main Puteri. (Norazit Selat, Ed.). Kuala Lumpur: Persatuan Muzium Malaysia.

Sabtu, M.S. (2002). Tamadun Awal Lembah Bujang. Kuala Lumpur, Malaysia: Dewan Bahasa dan Pustaka.

Osman, M.T. (1989). Malay Folk Beliefs: An Integration of Disparate Elements. Kuala Lumpur: Dewan Bahasa dan Pustaka.

Abdul Aziz, M.I. (1980). Cerita Dewa Muda. Kuala Lumpur: Kementerian Kebudayaan Belia Dan Sukan.

Abdul Halim, N. (1994). Permainan Mak Yong: Penilaian Dari Perspektif Hukum Islam.

Othman, N. (2000). Mesej Lagu-Lagu Mak Yong Dalam Masyarakat Melayu (Latihan IImiah). Kuala Lumpur, Malaysia: Jabatan Pengajian Media, Fakulti Sastera dan Sains Sosial Universiti Malaya.

Bujang, R. (2007). Wadah Wahana Seni Persembahan (Rohani Mohd Yusof, Ed.). Kuala Lumpur, Malaysia: Jabatan penerbitan Akademi Pengajian Melayu Universiti Malaya.

Skeat, W.W. (1984). Malay Magic Being an Introduction to The Folklore and Popular Religion of The Malay Peninsula. Singapore: Oxford University Press.

Shepperd, Mubin. (1983). Taman Saujana: Dance Drama Music and Magic in Malay Long and Not So Long Ago. International Book Store. 
Suwardi M. S. (2008). Dari Melayu ke Indonesia: Peranan Kebudayaan Melayu dalam Memperkokoh Identitas dan Jati Diri Bangsa. Yogyakarta: Pustaka Pelajar.

Winstedt, R.O. (1982). The Malay Magician: Being Shaman, Saiva and Sufi. London: Routledge. 